BBA 46405

\title{
THIN-LAYER CHROMATOGRAPHY OF PIGMENTS FROM REACTION CENTER PARTICLES OF RHODOPSEUDOMONAS SPHEROIDES
}

\author{
T. BEUGELING, L. SLOOTEN AND P. G. M. M. BARELDS-VAN DE BEEK \\ Twente University of Technology, P.O. Box 2I7, Enschede (The Netherlands) and Biophysical \\ Laboratory of the State University, Schelpenkade ${ }_{4} 4$, Leiden (The Netherlands)
}

(Received June 5 th, I972)

SUMMARY

I. Pigments extracted from reaction center particles of Rhodopseudomonas spheroides were separated and identified by means of thin-layer chromatography.

2 . The results strongly suggest that bacteriochlorophyll $a$ is the only bacteriochlorophyll pigment present in reaction centers.

3. Other compounds identified are bacteriopheophytin $a$, ubiquinone-Io and spheroidene.

\section{INTRODUCTION}

During the past few years a number of papers have been published, dealing with the isolation of photochemically active reaction center particles from photosynthetic bacteria (e.g. refs I-6). In these particles the light-harvesting bacteriochlorophyll and most of the other accessory pigments such as carotenoids, have been removed. The particles still contain specialized bacteriochlorophylls, P8oo and P870 (ref. 7), of which the latter is reversibly photooxidizable*. A pigment absorbing at about $756 \mathrm{~nm}$, which was assumed to be bacteriophosphytin ${ }^{6,7}$, and ubiquinone ${ }^{4,6,9}$ are also present in the preparations.

It has recently been concluded that $\mathrm{K}_{3} \mathrm{Fe}(\mathrm{CN})_{6}$-treated chromatophores from Rhodospirillum rubrum and $\mathrm{K}_{2} \mathrm{IrCl}_{\mathbf{6}}$-treated chromatophores from $R$. rubrum and Rhodopseudomonas spheroides, in which the light-harvesting bacteriochlorophyll had been destroyed, contained bacteriochlorophyll $a$ as the only type of bacteriochlorophyll pigment ${ }^{10}$. In that study extracts of the particles were analyzed by means of thin-layer chromatography and spectra were recorded of the isolated pigments. However, the visible spectrum of reaction center bacteriochlorophyll showed, in addition to the characteristic absorption maxima of bacteriochlorophyll $a$, prominent peaks at 433 and $675 \mathrm{~nm}$. It was assumed that the isolated reaction center bacteriochlorophyll was still contaminated with one or more degradation products from the bulk bacteriochlorophyll, present in the rather impure particles. The present chromatographic investigations were carried out with purified reaction centers of $R p s$.

* Although the absorption peaks near 800 and $865 \mathrm{~nm}$ are commonly called $\mathrm{P} 800$ and $\mathrm{P} 87^{\circ}$, they possibly are more properly described as the joint property of a set of closely interacting molecules in the reaction center, and not as the separate manifestations of independent molecules (see ref. 8). 
spheroides in order to elucidate this problem and in order to identify other pigments which are present in these preparations.

The results strongly suggest that the pigments of both $\mathrm{P} 800$ and $\mathrm{P} 870$ are identical with bacteriochlorophyll $a$. Further, it was found that the ubiquinone present in the reaction center particles is ubiquinone-Io. Bacteriopheophytin $a$ and spheroidene were also isolated with the help of thin-layer chromatography.

\section{MATERIALS AND METHODS}

Reaction center particles were prepared from chromatophores of $R p s$. spheroides as previously described by one of $\mathbf{u s}^{6}$. Briefly, chromatophores were incubated with $0.3 \%$ sodium dodecyl sulphate and layered on a $0.5 \mathrm{M}$ sucrose solution. After centrifugation at $200000 \times g$, the reaction center particles were isolated from the supernatant layer. They were further purified by treatment with Triton $\mathrm{X}$-roo and urea at $\mathrm{pH}$ Io, followed by a sucrose gradient (o.I-I M) centrifugation at $200000 \times g$. The reaction center particles obtained in this way were called AUT-RC particles.

The solvents used for extraction and chromatography were of analytical grade (Merck and $\mathrm{BDH}$ ). Ubiquinone-6 and ubiquinone-Io were purchased from Sigma.

Methanol extracts for chromatography were made from freeze-dried particles which were kept in the dark. The extracts were prepared just before chromatography.

The adsorbent used for thin-layer chromatography was Kieselgel G, obtained from Merck.

Thin-layer plates were developed in the dark. The spotting of the samples and elution of the spots from the scraped off adsorbent layer was carried out in dim light.

Spectra were recorded with a Cary Model I4 R spectrophotometer equiped with a scattered light transmission assembly.

\section{RESULTS AND DISCUSSION}

The absorption spectrum of an AUT-RC preparation from Rps. spheroides is shown in Fig. IA of ref. 6. The spectrum shows a low absorption around $685 \mathrm{~nm}$, proving that the reaction center particles contain only small amounts of degradation products from the bulk bacteriochlorophyll, as compared to the preparations used before ${ }^{10}$.

A good separation of the pigments from AUT-RC particles was obtained with thin-layer chromatography in which a mixture of light petroleum, acetone and $n$-propanol (see the text of Fig. I) was used as the mobile phase. This solvent mixture is a variation of a solvent system given by Lynn Co and Schanderl ${ }^{11}$ for the separation of plant pigments.

Fig. I shows the result of a separation. A bright blue spot is indicated with $R$. In a separate experiment, extracts of both AUT-RC particles and whole cells of $R p s$. spheroides were chromatographed on the same plate. In this way it was established that the $R_{F}$ value of spot $\mathrm{R}$ was the same as that of bacteriochlorophyll $a$.

It must be noted here that in the experiments with $\mathrm{K}_{3} \mathrm{Fe}(\mathrm{CN})_{6^{-}}$and $\mathrm{K}_{2} \mathrm{IrCl}_{6}-$ treated chromatophores mentioned above ${ }^{10}$, three different combinations of mobile 

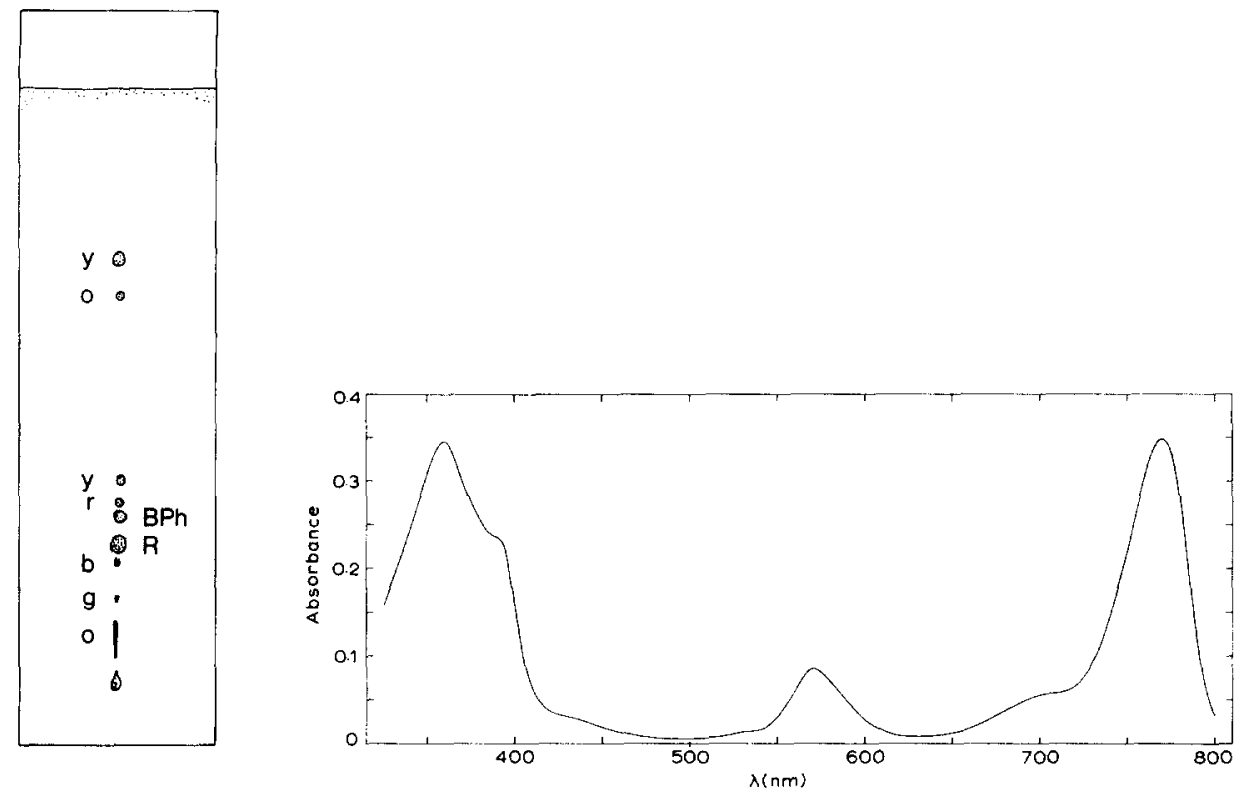

Fig. I. Thin-layer chromatography of a methanol extract from AUT-RC particles of Rps. spheroides. Adsorbent: Kieselgel $G$ (Merck), not activated, $0.3 \mathrm{~mm}$ thickness. Developing solvent: light petroleum (boiling range $60-80{ }^{\circ} \mathrm{C}$ )-acetone-n-propanol $(80: 10: 5, v / v / v)$. Developing time: 3o min. Indicator: none. The methanol extract was spotted on the place of the lowest spot; the solvent front is shown at the top of the drawing. $R$, reaction center bacteriochlorophyll. $\mathrm{BPh}$, bacteriopheophytin $a$. The spots of $\mathrm{R}$ and $\mathrm{BPh}$ are blue and purple, respectively. Yellow spots are indicated with $y$. An orange spot and an orange band are indicated with $o$. A green spot, $a$ blue spot and a reddish spot are indicated with $g$, b and $r$, respectively.

Fig. 2. Absorption spectrum of reaction center bacteriochlorophyll in acetone, isolated after preparative thin-layer chromatography of a methanol extract from AUT-RC particles of $R p s$. spheroides.

and stationary phases were used. Also in these cases the $R_{F}$ value of the blue spot was the same as that of bacteriochlorophyll $a$.

The absorption spectrum of the isolated blue pigment is given in Fig. 2 and peak maxima and relative intensities are listed in Table $I$, together with peak characteristics of bacteriochlorophyll $a$. The most plausible interpretation of our data is that the blue spot on the thin-layer chromatogram was bacteriochlorophyll $a$, and that this compound is responsible for the peaks near 800 and $865 \mathrm{~nm}$ in the reaction center preparations.

The spectrum of Fig. 2 does not show additional absorption peaks at 675 and $433 \mathrm{~nm}$. This proves that the peaks at these wavelenghts found in earlier experiments ${ }^{10}$ in fact originated from degradation products of the bulk bacteriochlorophyll, present in the crude starting material.

A quantitative analysis of reaction center bacteriochlorophyll could not be made since the yield of recovery of bacteriochlorophyll from cells, chromatophores and reaction centers was low and rather variable (about $30 \%$ ).

A small blue spot on the chromatogram, shown in Fig. I, which has a lower $R_{F}$ value than reaction center bacteriochlorophyll, is marked b. Such a spot was also 


\section{TABLE I}

PRINCIPAL LIGHT ABSORPTION MAXIMA AND RELATIVE INTENSITIES IN ACETONE FOR ISOLATED REACTION CENTER BACTERIOCHLOROPHYLL AND BACTERIOPHEOPHYTIN $a$

Values from the literature for both bacteriochlorophyll $a$ and bacteriopheophytin $a$ are given for comparison. Maxima of bacteriochlorophyll $a$ and bacteriopheophytin $a$ (literature) measured in ether, are also given (BChl, bacteriochlorophyll $a ; \mathrm{BPh}$, bacteriopheophytin $a$ ).

\begin{tabular}{|c|c|c|c|c|c|c|}
\hline \multirow{2}{*}{$\begin{array}{l}\text { Pigment } \\
\begin{array}{l}\text { Reaction center bacteriochloro- } \\
\text { phyll from AUT-RC particles }\end{array}\end{array}$} & \multicolumn{6}{|c|}{$\lambda_{m a x}(n m)$ and velative intensities (in parentheses) } \\
\hline & & & & & & \\
\hline phyll from AUT-RC particles & $359(99)$ & $392(67)$ & $57^{\circ}(25)$ & & $705(17)$ & $77^{\circ}(100)$ \\
\hline BChl (ref. I9) & $35^{8}(97)$ & $390\left(5^{8}\right)$ & $577(28)$ & & & $773(100)$ \\
\hline $\begin{array}{l}\text { BChl from Rps. spheroides } \\
\text { (ref. 2o) }\end{array}$ & $358(98)$ & $390(\mathrm{sh})$ & $578(27)$ & & & $77^{1}(100)$ \\
\hline $\begin{array}{l}\text { BChl from R. rubrum } \\
\text { (in ether) }\end{array}$ & $360(76)$ & $392(56)$ & $570(23)$ & & $710(\mathrm{II})$ & $773(100)$ \\
\hline BPh from AUT-RC particles & $357(100)$ & $382\left(5^{8)}\right.$ & $520(27)$ & $6 I 6(8)$ & 676 (I 5$)$ & $747(59)$ \\
\hline $\begin{array}{l}\text { BPh from } R p s . \text { spheroides } \\
\text { (refs } 19,20)\end{array}$ & $357(100)$ & $385(52)$ & $523(27)$ & & $675(\mathrm{II})$ & $745(48)$ \\
\hline $\begin{array}{l}\text { BPh from R. rubrum } \\
\quad \text { (in ether, ref. } 2 \mathrm{I} \text { ) }\end{array}$ & $357(100)$ & $3^{8} 7(5 \mathrm{I})$ & $528(23)$ & $6 \mathrm{I} 6(4)$ & $680(\mathrm{I} 4)$ & $75^{\circ}(6 \mathrm{I})$ \\
\hline
\end{tabular}

found after chromatography of extracts from whole cells and crude reaction centers ${ }^{10}$. Only small amounts of this pigment were observed. This seems to exclude the possibility that it has an important role in photosynthesis. It is conceivable that the compound is a degradation product of bacteriochlorophyll $a$. The green pigment $g$ in Fig. I may also be such a degradation product.

According to Clayton and co-workers ${ }^{8}$ purified reaction centers of $R p s$. $s p h e-$ roides contain fixed amounts of bacteriopheophytin. The absorption band at $756 \mathrm{~nm}$ in our AUT-RC particles also indicates the presence of bacteriopheophytin. This was confirmed with thin-layer chromatography. A purple spot was observed on the chromatogram of Fig. I, which is marked BPh. The spectrum of the pigment is given in Fig. 3 and peak characteristics are listed in Table I, together with values for bacteriopheophytin $a$ from the literature. From these data it is evident that the isolated compound is bacteriopheophytin $a$. Whether this pigment is involved in primary reactions of bacterial photosynthesis remains open to speculation.

It is well known that reaction center particles from purple bacteria contain ubiquinone $e^{4,6,9}$. In AUT-RC particles from $R p s$. spheroides ${ }^{6}$ and in $\mathrm{K}_{3} \mathrm{Fe}(\mathrm{CN})_{6^{-}}$ treated chromatophores from $R$. rubrum ${ }^{4}$ the molecular ratio of ubiquinone and P870 was found to be approximately I: I. Measurements of EPR spectra ${ }^{12}$ and of the difference spectrum and kinetics of light-induced ultraviolet absorbance changes ${ }^{\mathbf{1 3}}$ in reaction centers of $R p s$. spheroides indicate that ubiquinone acts as the primary electron acceptor in a one electron reaction. Therefore, it is important to characterize it completely. In this connection it is interesting to note that the ubiquinone present in $\mathrm{K}_{3} \mathrm{Fe}(\mathrm{CN})_{6}$-treated chromatophores from $R$. rubrum was found to be ubiquinone-Io (ref. $\mathrm{r}_{4}$ ).

The position of ubiquinones on the chromatogram of Fig. I is just below the upper yellow spot. They can be detected if the chromatogram is sprayed with Rhodamine $\mathrm{B}$ in ethanol and examined in ultraviolet light. Using the procedure outlined before ${ }^{14}$ we found that the ubiquinone isolated from a thin-layer plate, 


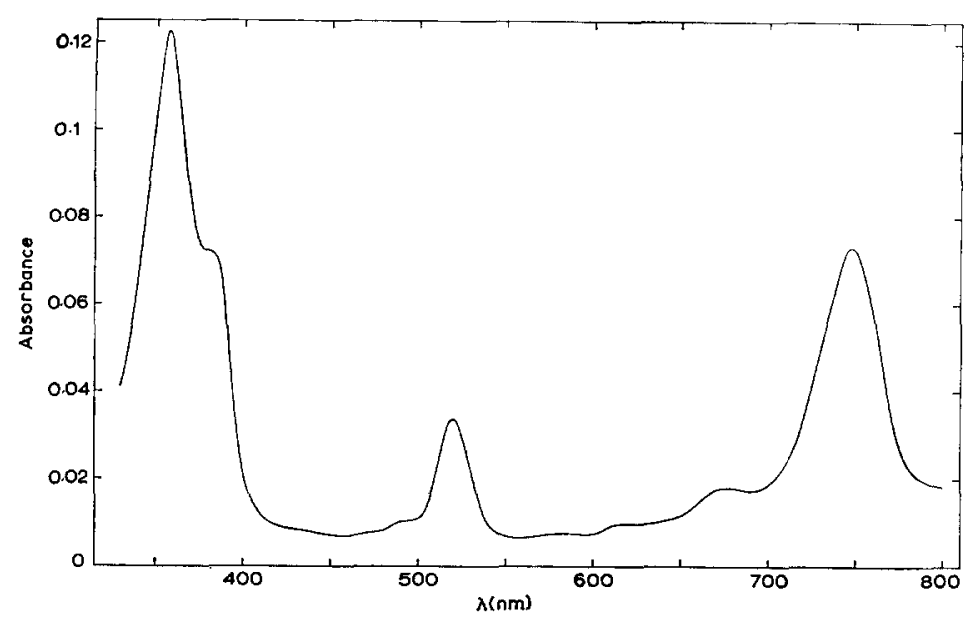

Fig. 3. Absorption spectrum of bacteriopheophytin $a$ in acetone from an AUT-RC preparation of $R$ ps. spheroides, after thin-layer chromatography.

as shown in Fig. I, was ubiquinone-Io. This result is not surprising, because relatively large amounts of ubiquinone-Io were found in whole cells and chromatophores of $R p s$. spheroides. The latter data are in agreement with those of Maroc et al. ${ }^{15}$, but Takamiya et al. ${ }^{16}$ reported that ubiquinone- 9 is present in chromatophores of $R p s$. spheroides.

The spots indicated with $\mathrm{y}, \mathrm{o}$ and $\mathrm{r}$ presumably come from carotenoids. So far, carotenoids have not been removed completely from the AUT-RC particles. It is not clear, whether these pigments play an important role at all, since they are lacking in reaction centers prepared by Reed and Clayton ${ }^{5}$ and, since blue green mutants show normal photosynthetic growth with no carotenoids.

Carotenoids were extracted and purified according to a procedure which is generally used for the extraction of ubiquinone (ref. I7, except that no ferricyanide was added). The isolated material was thereafter spotted on a thin layer plate which was developed with a mixture of chloroform and benzene (I:I, V/v). The pigment from the biggest spot $\left(R_{F}\right.$ value 0.57$)$ showed absorption maxima at 428,454 and $484 \mathrm{~nm}$ and a shoulder at $404 \mathrm{~nm}$. These spectral characteristics are indicative of spheroidene (Pigment $\mathrm{Y}$ of ref. I8).

\section{ACKNOWLEDGEMENTS}

One of us (L.S.) was supported by the Netherlands Foundation for Chemical Research (S.O.N.), financed by the Netherlands Organization for the Advancement of Pure Research (Z.W.O.). Thanks are due to Dr J. Amesz for stimulating discussions.

\section{REFERENCES}

I R. K. Clayton, Biochim. Biophys. Acta, 75 (I963) 312.

2 P. A. Loach, G. M. Androes, A. F. Maksim and M. Calvin, Photochem. Photobiol., 2 (1963) 443.

3 R. K. Clayton and W. R. Sistrom, Photochem. Photobiol., 5 (1966) 66r.

4 T. Beugeling, Biochim. Biophys. Acta, I53 (1968) I 43.

Biochim. Biophys. Acta, 283 (1972) 328-333 
5 D. W. Reed and R. K. Clayton, Biochem. Biophys. Res. Commun., 30 (I968) 47 I.

6 L. Slooten, Biochim. Biophys. Acta, 256 (I972) 452.

7 R. K. Clayton, Photochem. Photobiol., 5 (I966) 669.

8 R. K. Clayton, H. Fleming and E. Z. Szuts, Biophys. J., I 2 (1972) 46.

9 D. W. Reed, J. Biol. Chem., 244 (I969) 4936.

ro T. Beugeling, in G. Forti, M. Avron and A. Melandri, Proc. and Int. Congr. Photosynth. Res., Stresa, 197I, Dr. W. Junk, The Hague, 1972, p. 1453.

I I D. Y. C. Lynn Co and S. H. Schanderl, J. Chromatogr., 26 (I967) 442.

12 G. Feher, M. Y. Okamura and J. D. McElroy, Biochim. Biophys. Acta, 267 (1972) 222.

13 L. Slooten, Biochim. Biophys. Acta, 275 (1972) 208.

I 4 T. Beugeling, in H. Metzner, Progress in Photosynthesis Research, H. Laupp, Jr, Tübingen, I969, p. IIOI.

I5 J. Maroc, H. de Klerk and M. D. Kamen, Biochim. Biophys. Acta, I62 (I968) 62 I.

16 K. Takamiya, M. Nishimura and A. Takamiya, Plant Cell Physiol., 8 (1967) 79.

17 K. Takamiya and A. Takamiya, Plant Cell Physiol., Io (r969) 363.

I 8 T. W. Goodwin, D. G. Land and M. E. Sissing, Biochem. J., 64 (1956) 486.

I9 A. Jensen and O. Aasmundrud, Acta Chem. Scand., I 7 (I963) 907.

20 A. Jensen, O. Aasmundrud and K. E. Eimhjellen, Biochim. Biophys. Acta, 88 (1964) 466.

2 I W. S. Kim, Biochim. Biophys. Acta, I 2 (I966) 392.

Biochim. Biophys. Acta, $283(1972)$ 328-333 